\title{
Eşcinsellik Temelli Nefret Söylemi İçeren İletilerin Twitter'da İncelenmesi
}

\author{
Zeynep Benan Dondurucu (Arş. Gör.) \\ Kocaeli Üniversitesi İletişim Fakültesi \\ zdondurucu@yahoo.com
}

Başvuru Tarihi: 02.05.2018

Yayına Kabul Tarihi: 12.06.2018

Yayınlanma Tarihi: 30.07.2018

\section{Öz}

Yeni medya kitle iletişim araçlarına kıyasla bireye tanıdığı içerik üretim özgürlüğü ve editöryal denetiminden bağımsızlık gibi özelliklerle, ifade özgürlüğü alanının genişlemesini sağlamıștır. Ancak, yeni medya platformlarında iletilerin kimler tarafından üretildiğinin bilinmemesi ve iletilerin yayılma sürecinde kontrol mekanizmalarının bulunmaması; ifade özgürlügü ve nefret söylemi arasındaki sınır çizgisini bulanıklaştırmaktadır. Kullanıcı türevli içerikler olarak ortaya çıkan yeni medya iletileri, etnik köken, din ya da cinsel yönelim farklılıklarına bağlı olarak bir grubu ya da kişiyi ötekileştirme amaçlı olarak kullanılabilmekte ve hızla nefret söylemine dönüşebilmektedir. Bir yeni medya bileșeni olarak her gün milyarlarca tweet'in paylaşıldığı Twitter üzerinde çeşitli konularda nefret söylemi üretilmekte ve yayılmaktadır. Twitter'da, nefret söylemine maruz kalan gruplardan biri de cinsel yönelimleri nedeni ile ötekileștirilen eșcinsel bireylerdir. Bu bağlamda, çalışmada Twitter'da; eşcinsellik temelli nefret söyleminin üretim ve dağılım biçimlerinin belirlenmesi amacı ile; 15-30 Mayıs 2015 tarihleri arasında “\#eșcinsel” etiketi içeren iletiler, nitel ve nicel içerik analizi yöntemi ile konu, kaynak, nitelik, örtük ve açık ayrımcı ifadelere yer verilme durumu, biçim ve etkileşim değişkenleri açısından incelenmiştir.

Anahtar Kelimeler: Eşcinsellik, Yeni Medya, Nefret Söylemi, Twitter.

\footnotetext{
* Bu çalıșma 19-22 Mayıs 2016 tarihleri arasında Madrid/Ispanya'da düzenlenen 1. Uluslararası Bilimsel Araștırmalar İnsan ve Toplum Bilimleri Konferansı'nda Eşcinsellik Temelli Nefret Söylemi İçeren İletilerin Twitter'da İncelenmesi başlığıyla sunulan bildirinin genişletilmiş halidir.
} 


\title{
An Analysis Aabout Messages Which Include Homosexuality Based Hate Speech in Twitter
}

\author{
Zeynep Benan Dondurucu (Res. Asst.) \\ Kocaeli University Faculty of Communication \\ zdondurucu@yahoo.com
}

Date Received: 02.05.2018

Date Accepted: 12.06 .2018

Date Published: 30.07.2018

\begin{abstract}
New media environments have expanded the field of freedom of expression with their specific features such as independence from the editorial control and the content creation freedom which is supplied for the individuals. However, not knowing that messages are produced by whom and not having control mechanisms in the distribution process of the messages are blurring the boundaries line between freedom of expression and hate speech. The new media messages which are occurred as user-oriented contents can be used for differentiation aim of a group or a person depending on their ethnic background, religion or sexual orientation and they can be converted into hate speech very fast. Hate speech on various topics is being produced and spread in Twitter where millions of tweets are shared every day, as a new media component. The homosexual individuals are one of these groups who are exposed to hate speech in Twitter because of their sexual orientation. In this context, messages which contains "homosexual" hashtags are analyzed according to content, source, quality, usage of direct and indirect discriminatory statements, form and interaction variables with qualitative and quantitative content analysis method, between 15-30 May 2015, in Twitter for finding out the the production and distribution of homosexuality based hate speech.
\end{abstract}

Keywords: Homosexuality, New Media, Hate Speech, Twitter. 


\section{Giriş}

Geleneksel kitle iletişim araçlarına yönelik ön kabuller arasında medyanın bireyleri etkileyen ve biçimlendiren bir güç olduğu düşüncesi yer almaktadır. Geleneksel medyanın kitleleri etkisizleștiren tek yönlü iletişim yapısına karşın yeni medya, kullanıcı türevli içeriğin dolaşımına girmesine imkan tanıyarak çift yönlü bir iletişim biçimini mümkün kılmıştır. En önemli özellikleri etkileșim, eş zamansızlık ve kitlesizleştirme olan yeni medya; etkileşimlilik özelliği ile kaynak ve alıcının içeriği karşılıklı olarak șekillendirebileceği bir alan oluşturmuştur. Kitlesizleștirme ile birlikte ise; iletişim sürecinde tüm alıcılara aynı mesajın gönderimi yerine alıcıların özelliklerine bağlı olarak özel içerikler gönderilmeye başlanmış olup; kaynağın baskın rolü alıcının da sisteme dahil olması ile ortadan kalkmıştır. Yeni medyanın eş zamansızlık özelliği de; kaynak ve hedef arasındaki etkileșimin zaman ve mekan sınırları olmadan sürdürülebilmesi anlamını taşımaktadır (Rogers, 1986, 5-7). Ancak, bu yeni iletişim biçiminin, egemen düşünceden ne derece bağımsız olduğu önemli bir tartışma konusudur. Sistemin ideolojisini meşrulaştırması ve kitleler üzerinde egemen olabilmesi için devletin baskı aygıtlarını ve ideolojik aygıtlarını eş yönlü bir biçimde kullanması gerekmektedir. "Biz" ve "öteki" ekseninde karşıtlıklar üzerinde şekillenen ayrımcılık biçimleri, egemen sınıfların gücünü ötekileștirilen gruplar üzerinden meşrulaştırmaktadır. Ötekileştirilen kişi veya gruplar mensup oldukları ırk, din veya cinsel yönelimleri sebebi ile kamusal alan içerisinde ayrıştırıcı davranışlara maruz kalmaktadır. Yeni medya bireylere geleneksel medyaya kıyasla bir özgürlük alanı tanımakla birlikte; kullanıcılar tarafından denetimsiz olarak üretilen içerikler, nefret söylemi oluşumuna imkan tanıyarak "öteki” olarak adlandırılan gruplara yönelik hakim söylemi yeniden üreterek, yaymaktadır.

Ötekileştirme sürecini normalleștiren söylemsel bir pratik olarak karşımıza "nefret söylemi" çıkmaktadır. Nefret söylemine yönelik olarak evrensel bir tanım bulunmamakla birlikte; Avrupa Konseyi'nin Bakanlar Komitesi tarafından yayınlanan "nefret söylemi" konulu 97(20) sayılı Tavsiye Kararı'nda kavram; "Irkçı nefret, yabancı düşmanlığı, yahudi düşmanlığı ya da azınlıklara yönelik düşmanlık ile beraber hoşgörüsüzlüğe dayalı diğer ayırmcılık ve nefret biçimlerini yayan, teşvik eden ya da haklı gösteren tüm ifade biçimlerini kapsayacak" biçimde tanımlanmıştır. (Avrupa Konseyi, 2014, 34). Avrupa Konseyi Bakanlar Komitesi, üye devletlere yönelik $C M / \operatorname{Rec}(2010) 5$ sayılı Tavsiye Kararı'nda ise; "Lezbiyen, gay, biseksüel ve trans kişilerin cinsel yönelimleri nedeni ile transfobi ve homofobi temelli ayrımcılık biçimlerine yüzyıllardır maruz kaldığını kabul ederek, bu kişilerin insan haklarından yararlanabilmesi için özel eylem gerektiğini kabul belirtmiş ve cinsel kimlik/cinsel yönelim kaynaklı nefret söyleminin hiç bir biçimde meşrulaştırılamayacağını ifade etmiştir." (Avrupa Konseyi, 2014, 8-12). Nefret söylemi homofobi temelli olarak cinsel azınlık gruplarına yöneldiğinde; kültürel inançlar, ön yargılar ve egemen ideolojiye bağlı olarak, ayrımcılık pratikleri şeklinde ortaya çıkmaktadır. Eşcinsellere yönelik olarak fiziksel şiddet, sözel şiddet, mizah, dışlama ya da öldürme gibi farklı eylem biçimlerinin hayata geçirmesi ile ortaya çıkan homofobi, en şiddetli ayrımcılık biçimlerinden biri olarak nefret suçlarının ortaya çıkmasına da zemin hazırlamaktadır. ABD'de gerçekleștirilen çeşitli araştırmalar, nefret suçlarından etkilenen grupların başında eşcinsellerin geldiğini ortaya koymuştur (Başar vd. 2010, 73, Göregenli 2009, 49 ve Göregenli 2011a, 49). Yeni medya ortamlarının kullanıcıya sağladığı içerik üretme özgürlügü ile İnternet üzerinde hızlıca yayılma imkanı bulan homofobik nefret 
söylemi; toplumsal yaşamın ideolojik ve kültürel temellerinden bağımsız olarak değerlendirilemez. Bu bağlamda, gündelik yaşam içerisinde; eşcinsellere yönelik olarak hayata geçirilen ötekileştirme pratikleri ve nefret söylemi; yeni medyanın sağladığı yayılım olanakları birlikte etki alanını genişletmiştir.

Nefret söylemi, toplumsal bilinç yapısında doğrudan bir rol oynayan ötekileștirme pratiklerinin bir uzantısıdır. Devlet, ideolojik aygıtları aracılığıyla toplumun bilinç yapılarında etkin bir rol oynayarak; ötekileştirilen sınıfların içerisinde bulundukları durumu kabullenmelerini sağlamaktadır. Devletin ideolojik aygıtlarından biri olan kitle iletişim araçları bu kabullenmeyi hegemonya yaratarak sağlamaktadır. Hegemonya en iyi biçimde rızanın örgütlenmesi olarak tanımlanmakta olup; arzu edilen bilinç biçimlerinin gönüllü olarakinşa sürecidir (Barrett, 1997, 5). Hegemonya ifadesi, Gramsci'nin “Hapishane Defterleri” isimli çalışmasında anahtar kavram olarak yer almaktadır. Düşünür, kavramı işçi sınıfı-burjuva devleti çatışmasında; proleteryanın toplumsal taban olarak varlığını sürdürmesini sağlayan ittifaklar sistemi olarak değerlendirmiștir (Gramsci, 1978, 443 ve Bottomore, 2005, 273). Hegemonyayı oluşturan ve sürdüren en önemli unsurlardan biri olarak karşımıza "devletin ideolojik aygıtları" çıkmaktadır. Althusser (2003) devletin baskı aygıtları ve devletin ideolojik aygitları olarak, temel kontrol mekanizmalarını ikiye ayırmaktadır. Devletin baskı aygıtları hükümet, ordu, polis, mahkeme, hapishane gibi doğrudan baskı unsurları olarak ortaya çıkarken; ideolojik aygıtlar arasında ise okul, sendika, dini kurumlar, aile gibi bilinç inşası süreçlerini kontrol eden kurumlar yer almaktadır (Güngör, 2001, 222). Bu bağlamda, Althusser "ideoloji” kavramını, öznelerden üretilen ve farklı yöntemlerle toplumsal yapı içerisinde hareketlilik yaratan bir pratik olarak ele değerlendirmektedir. Bireylerin dünyaya bakış açısını şekillendiren temel etmen olarak ideolojiyi ele alan düşünür; ideolojinin taşıyıcı unsurları olarak gelenek, din, kitle iletişim araçları gibi araçlar üzerinde durmaktadır (Althusser 2003, 58, 76).Foucault ise, hakim ideoloji içerisinde bedeni dışlanan ve görmezden gelinen bir olgu olarak ele almıştır. Düşünüre göre Hristiyanlıkla birlikte ortaya çlkan beden üzerinden bireyin kontrol edilme isteği; modernizmle birlikte oluşan yeni toplumsal düzende devletin kontrol mekanizmalarından birine dönüşmüştür (Özdemir Akgündüz, 2013, 2) Foucault'a göre; "İktidar her zaman ve her yerde bulunmaktadır." (Foucault, 1998, 99). Bu bağlamda, cinsellik kalıplarının belirlenmesi, kadınların veya eşcinsellerin ötekileştirilmesi gibi uygulamaların tamamında iktidarın her zaman ve heryerde bulunmasına bağlı olaraksiyasal ilişkiler yer almaktadır (Foucault, 2000, 191). Bu nedenle, düşünüre göre toplumu sürekli denetim altında tutmanın yollarından biri bireyleri bedenlerinde oluşan yoksunluk duygusunu kabul etmeye zorlayarak; arzunun verdiği hazzı, günah ve ahlaksızlıkla eşdeğer tutmak olmuştur. Dolayısıyla heteroseksüel ilişkinin meşrulaștırılması ile; toplumun cinsel tutumları denetim altında tutularak; hegemonik söylemin bir parçası olarak cinsel aykırılıklar giderilmeye çalışılmaktadır (Özdemir Akgündüz, 2013, 2-6). Bu bağlamda hakim ideolojinin cinsel yönelimler üzerinden toplumu kontrol etme çabasının bir uzantısı olarak; kamusal alanda eşcinsellik sürekli ötekileştirilmektedir. Yeni medya da etkileşimli bir iletişim platformu olarak hegemonyadan bağımsız bir alan değildir. Ayrıca, yeni medyada kullanıcının içerik oluşturabilecek bir özellik kazanması ile birlikte nefret söylemi kolayca yayılma imkanı elde etmiştir. Geleneksel medya aracılığı ile üretilen eşcinsellik temelli nefret söyleminin sadece alıcısı konumunda olan birey, Twitter gibi sosyal medya siteleri üzerinde hegemonik söylemi alıcı olarak meşrulaştırmanın yanı sıra içerik 
üreticisi olarak dağıtma imkanı elde etmiştir. Dolayısıyla, kullanıcılar eşcinselliğe yönelik baskın ideoloji ile benzer düşüncelerini, Twitter üzerinde "tweet" atarak oluşturabilir; "retweet" ederek yayabilir veya "beğeni" yaparak onaylayabilirler; ya da benzer bir içerik oluşturabilirler

\section{Eşcinsellik Kavramına Yönelik Farklı Yaklaşımlar}

Aynı cinse karşı bir cinsel yönelim duyulması veya ilişki kurulması olarak tanımlanan "eşcinsellik" kavramı; İngilizcede "homosexuality" sözcüğü ile ifade edilmektedir ve kökenini Yunanca "homos" kelimesi ile Latince "sexus" sözcügünden almaktadır (McCary, 1967, 279 ve Nişanyan, 2002, 184). Cinsel yönelim temelli olarak "eşcinsellik" kavramı; kadın ve erkeklerin kendi cinsinden olan bireylere karşı duydukları duygusal, erotik ve cinsel yönelimi tanımlamaktadır. Eşcinsel olan kadınlar için "lezbiyen"; erkekler için ise "gay" terimi kullanılmakta olup; bu iki ifade eşcinselliği tıp terimi olarak tanımlayan "homoseksüel" kavramından bir kopuş niteliği taşıyarak kavramı toplumsal bir temele oturtmuştur (KAOS GL, 2015). Türkiye'de ise kendi cinsinden bireylere karşı cinsel bir yönelimi olan kadın ve erkekler için gündelikyaşam içerisindeyoğunlukla "eşcinsel" ifadesi kullanılmaktadır (Alacaoğlu, 2013,15). Eşcinsellik olgusuna yönelik olarak farklı yaklaşımlar tarihsel süreç içerisinde değişiklik göstermiş olup; bazı toplumlar tarafından sakıncalı bulunan eşcinsellik, bazı toplumlar tarafından normal karşılanmıştır.

Eşcinselliğin tarihi açısından; ilk akla gelen topluluklardan biri olan Antik Yunan Medeniyeti'nde "eşcinsellik"; günümüzün toplumsal yapısından farklı olarak yetişkin erkek ile genç erkek arasındaki cinsel ilişki biçimini karşılamaktadır. $\mathrm{Bu}$ bağlamda, Antik Yunan toplumunda, cinsel yönelim kategorileri açısından "eşcinsellik" ve "heteroseksüellik" gibi farklı tanımlamalar yer almakla birlikte; olguya yaklaşımları günümüz toplumundan farklıdır (Gezgin, 2010, 222 ve Padgug, 2001, 54). Antik Yunan toplumu ekseninde, eşcinselliği felsefi bir perspektiften irdeleyen Foucault; "Cinselliğin Tarihi” isimli eserinde kavramı haz olgusu ekseninde değerlendirmiştir. Antik Yunan düşünürlerinin; heteroseksüel ve homoseksüel ilişki biçimlerine modern ahlak anlayıșının genel geçer kabüllerinden farklı yaklaştığını ileri süren düşünür; Antik Yunan medeniyetinde insanların karşı cinsleri ve kendi cinslerine yönelik olarak duyduğu aşk ve haz arayışı arasında bir farklılık olmadığını belirtmiştir. Bu bağlamda; düşünür bir kadını ya da erkeği arzulamanın, doğanın insanın içerisine yerleştirdiği güzel olana ulaşma isteği ile bağlantılı bir durum olduğunu dile getirmiştir (Foucault, 1998, 201-203).

Eşciselliğe yönelik olarak, Museviliğin kutsal kitabı Tevrat'ta “Kadınla olduğu gibi erkekle yatma, bu tiksindiricidir." ifadesi yer almaktadır (Leviticus, 18,22). İslamın kutsal kitabı olan Kur'an'ın Şuara Suresi'nde ise; “Rab’binizin sizin için yarattığı eşleri bırakıp insanlar arasından erkeklere mi yanașıyorsunuz? Siz haddini aşan bir topluluksunuz." ifadesi yer almaktadır (Kur'an, 165-166). İncil'de doğrudan eşcinselliğin yasaklanmasına yönelik olarak açık bir ifade bulunmamakla birlikte; Hristiyanlığın Roma İmparatorluğu'nda yayılması ile birlikte; eşcinsellik bir günah olarak görülmeye başlanmıştır. Bu dönem içerisinde, döllenme/üreme ile sonuçlanmayan ve cinsel haz amaçlı olarak gerçekleşen tüm ilişki biçimlerinin günah olarak görüldüğü teolojik yaklașıma bağlı olarak; eșcinselliğin de dahil olduğu ilişki türlerinin bütünü şehvet düşkünlüğü olarak nitelendirilerek; doğaya aykırı bir biçimde değerlendirilmiştir. (Stanford Encyclopedia of Philosophy, 2011). Günümüz toplumlarında da; dini ön kabullere bağlı olarak; eşcinselliğin günah 
olarak tanımlanmasının temelinde üreme değil haz amaçlı olarak gerçekleşmesi yer almakta olup; Tek Tanrılı dinlerin cinselliğin dünyaya sadece çocuk getirme amaçlı olarak gerçekleștirilebileceği savı, eșcinselliğin de dahil olduğu tüm hazların günah kategorisinde değerlendirilmesinde etkili olmuştur. Dinin iktidar erki olarak güç kaybetmesi ve hukuk kurallarının toplumsal düzende etkili olması ile birlikte; eşcinsellik zaman içerisinden "günah" yerine "suç" olarak nitelindirilmeye başlanmıştır ve hukuk kuralları çerçevesinde yasaklanmaya çalışılmıştır (Candansayar, 2011, 154-156).

Çağdaş eşcinsellik tartışmaları ise, bir kimlik meselesi olarak bilimsel alana 19. Yüzyılın ortalarında girmiştir. Bu dönemde tıp bilimi, eşcinselliği bir hastalık olarak görüp tedavi etmeye çalışmıştır. Sanayi Devrimi ile birlikte modern toplum yapısına geçilmesi ve orta sınıfın güçlenmesi, aile kurumuna verilen değerin artması sonucunu doğurmuştur. Ahlaki yönden temizliği her iki cins için de mecburi gören katı bir anlayış ekseninde; evliliğin ve ailenin kavramsal olarak yüceltilmesi eşcinselliği önemli bir hedef haline getirmiştir. Bu nedenle, 19. ve 20. yy. sonlarında, toplum tarafından eşcinsellik önemli bir sorun olarak görülmeye başlanmıștır. Ayrıca, dini önkabuller ve Viktoryan dönemin temel tıbbi söylemlerine bağlı olarak eşcinselliğin hastalık olarak görülmeye devam edilmesi nedeni ile, 20. yüzyılın ilk yarısına kadar, pek çok eşcinsel birey toplumsal yaşamda aktif olarak yer almaktan kaçınmıştır (Segal, 1992, 177-179). Bu dönemde, psikoloji biliminin gelişimi ile birlikte; insanı bedenen ve ruhen dejenarasyona uğratan bir hastalık olarak görülmeye başlanan eşcinsellik, 20. Yüzyılın başlarından itibaren zorla tedavi edilmeye başlanmıştır. Özellikle 1950 ve 1970’li yıllar eşcinsellere psikanaliz, elektroşok, kusturma gibi yöntemlerle zorla tedavi uygulamalarının giderek yaygınlaştığı dönemler olmuştur (Candansayar, 2009, 71). Böylece, eşcinselliğin psikolojik bir hastalık olarak görülmeye başlanması ile "günah" ve "suç" nitelendirmeleri üzerinden toplumsal hayatta ayrımcılık pratikleri ile karşı karşıya kalan eşcinsel bireyler; farklı tedavi yöntemlerinin nesnesi haline gelmeye başlamıştır (Çabuk ve Candansayar, 2010, 85). 1935 yılında Amerikan Psikiyatri Birliği (APA) tarafından eşcinsellik, "patolojik cinsellikli psikopatik kişilik" olarak tanımlanırken; aynı kurum tarafından 1952 yılında "sosyopatik kișilik bozukları" ana kategorisinin bir alt grubu olarak cinsel sapkınlıklar arasında tanımlanmıştır. APA, ancak 1973 yılında eșcinselliği, homoseksüel bireylere yönelik ayrımcılığın ve ötekileştirmenin engellenmesine yönelik kendi içerisinden gelen çağrılar sonucunda hastalık olmaktan çıkartmıştır (Yetkin, 2009, 79). Aynı yıl, Amerikan Psikoloji Derneği eşcinselliği bir cinsel yönelim olarak kabul etmiştir (American Psychological Association, 1973). 1990 yllında ise Dünya Sağlık Örgütü eșcinselliği doğal bir durum olarak tanımlayarak ruhsal hastalıklar listesinden çıkarmıştır (World Health Organization, 2011). Eşcinselliğin bir cinsel yönelim olarak kabul edilmesi sürecinde; 1960'larda eşcinsellerin kamusal alanda varlıklarını hissettirmesi ve özgürlük arayışlarına hız vermesine bağlı olarak eylemci kimlikleri ile sabit toplumsal cinsiyet kalıplarını aşarak; eşcinsel yönelimi anormal kategorisinin dışına çıkarma amaçlı çalışmaları etkili olmuştur. Böylece, eșcinsel alt kültürler kendi içlerinde hızla büyüyerek toplumsal alanda etkin bir biçimde faaliyet göstermeye başlamıştır (Segal, 1992, 188). Yaşanan gelişmelere rağmen, din temelli olarak yönetilen ülkelerde eşcinsellerin ağır cezalara maruz kalması ve bazı sağlık çalışanları tarafından çeşitli yöntemlerle tedavi edilmeye çalışılmaları gibi olumsuzluklar günümüzde de devam etmekte olup; eşcinsel 
bireylerin toplumsal hayatta karşılaştıkları temel sorunların başında ise ayrımcılık ve ötekileştirme pratiklerinin sürekli üretimi ve homofobi yer almaktadır.

\section{Homofobi ve Eşcinsellik Temelli Nefret Söylemi}

Homofobi, temel anlamı ile eşcinselliğe ve eşcinsel eylemlerde bulunanlara yönelik olarak hissedilen korku, nefret ya da hoşlanmama durumunu karşlayan bir sözcüktür (Fone, 2000, 5). Homofobinin, cinsel bir ön yargl, kişisel bir korku ya da mantıksız bir inanç olmanın ötesinde; kültür ve toplumsal yaşam sistemlerine bağlı olarak ortaya çıktığı görülmektedir. Homofobinin temelinde yer alan ayrımcılık ve şiddet pratikleri, özünde iktidarların politika üretme biçimleri ile doğrudan bağlantılıdır. Dolayısıyla, seksizmin de bir uzantısı olarak işleyen homofobi, erkekliğin yüceltilmesine bağlı olarak insanlığın korunması ve kontrolü için; farklı cinsel yönelimlere sahip kişilere yönelik fiziksel ve sözel şiddet uygulanması biçiminde ortaya çıkmaktadır. Ayrıca, homofobi temelde cinsiyetçilik ile bağlantılı olarak, erkekliğin yüceltildiği bir sistemsel ideoloji ve toplumsal yapının inşası için de temel bir işlev görmektedir (Göregenli, 2011b, 354-355 ve Göregenli, 2010, 23). Bu bağlamda, homofobi hegemonik erkeklik biçimlerinin yeniden inşa edilmesi için bir araç haline gelmektedir.

Connell (2002) “hegemonik erkeklik" kavramını; bir kültürde farklı erkeklik biçimleri içerisindeki iktidar mücadelesi üzerinden; diğer erkeklik biçimleri üzerinde baskı kuran erkeklik biçimi olarak tanımlamaktadır (Connell, 2002, 142). Bu bağlamda, hegomonik erkeklik, kadınlar ve kendi kurgusu dışında kalan tüm erkekler üzerinde egemenlik kurmayı amaçlayan; saldırganlık ve şiddetten beslenen bir ataerkil kurgu ve söylemdir (Cengiz vd., 2004, 51). Böylece, heteroseksüel bir iktidar pratiği olarak hegomonik erkeklik; erkeklik değerine uymayanları tüm bireyleri ötekileştirmekte ve "öteki" kategorisinde kadınlar ve eșcinseller yer almaktadır (Oktan, 2008, 155). Alanyazında farklı erkeklik çalışmaları arasında; erkeğin niteliğine yönelik sınıflandırmalar arasında kadınsı olan her şeyden kaçınma ve homofobi yer almakta olup; homofobiye bağlı olarak farklı cinsel yönelimlere sahip bireylere yönelik olumsuz tutum ve yargılar, erkeklik kalıpları içerisinde yer almaktadır (Pleck, 1995, 19 ve Kassing vd., 2005, 316). Bu nedenle, heteroseksüel erkekler; homofobiyi kendi kimliklerini "gerçek erkek" olarak inşa etmek ve erkekliklerini diğer erkekler üzerinde güç uygulamak için araç olarak kullanmaktadır (Ertan, $2010,7)$. Dolayısıyla, homofobi erkeklerin kadınları kendilerinden daha zayıf ve aşağı varlıklar olarak görmelerine bağlı olarak eşcinsel bireyleri de kadınsı özellikler taşıdıklarını düşündüğü için ötekileştirme eğilimi içerisine girmeleri sonucunda ortaya çıkmaktadır (Fone, 2000, 6).

Hegomonik erkeklik, homofobi ve eșcinsellik ilişkisi incelendiğinde, "gay" ler erkekliği bozan ve erkeklik kodlarına zarar veren bireyler olarak ötekileştirilirken; lezbiyenler; toplumsal olarak güç ve iktidarın simgesi olan erkek cinsel organının bu ilişki biçiminde yer almaması nedeni ile ayrımcılık ile karşı karşıya kalmaktadır. Bu durumun gündelik hayatta örnekleri; heteroseksüel erkeklerin lezbiyenlerin gerçek bir erkekle tanışmadıkları için; cinsel yönelimlerin kadınlara yönelik olduğuna dair söylemlerinde açıkça görülebilmektedir. Gayler ise; cinsel yönelimlerinin başka bir erkeğe yönelik olması ve birbirleri ile fiziksel temas içerisinde bulunmaları nedeni ile hegemonik erkeklik kodlarına ve davranış pratiklerine zarar veren bireyler olarak söylemsel ve fiziksel bazda şiddet içeren davranışlarla karşı karşıya kalabilmektedir. Homofobi temelli olarak ortaya çıkan söylemsel ve eylemsel pratikler, toplumsal 
yapı içerisinde geleneksel kitle iletişim araçlarında haber sunumlarından eğlence programlarındaki eşcinsel streotiplerine; gündelik dil içerisindeki kullanımlardan eşcinsel bireylere fiziksel zarar verilmesine kadar uzanan geniş bir yelpazede karşımıza çıkabilmektedir.

$\mathrm{Bu}$ bağlamda ideolojik ve kültürel olarak homofobi, gündelik yaşam içerisinde şiddetten küfüre, cana kastetmeden mizah yolu ile aşağılamaya ya da görmezden gelmeye kadar pek çok biçimde tezahür edebilmektedir (Göregenli, 2009, 49). Bu tutum ve davranışların temelinde eşcinsellerin topluma tehdit oluşturduğu savı ve homofobi yer almakta olup, aslında bu nedenlere bağlı olarak eşcinsellere uygulanan negatif tutum ve davranışlar eşcinseller için tehdit oluşturmaktadır (Bryant ve Vidal, 2008, 388). Eşcinsel bireylerin karşılaştığı sorunlar arasında ilk sıralarda yer alan homofobik nefret söylemi ve nefret suçlarının nedenleri arasında ise sistematik ötekileștirme pratikleri yer almaktadır.

Sözcük anlamı ile "Öteki” bilinenden ayrı, öbür, diğer gibi anlamlar taşımakta olup; her toplumsal yapı içerisinde "öteki" mutlaka yer almaktadır. "Ben", "Biz" ve "Öteki" gibi ikili karşıtlıklara bağlı olarak konumlandırılan kavramın ortaya çıkış sürecinde farklılaştırma ve ayrıştırma mekanizmaları yer almakta olup; bu mekanizmalar olumsuz ön yargılar ve streotipler yaratmaktadır (Nahya, 2011, 30). Günümüzün modern sosyal yapısı içerisinde "öteki” toplumun dışına itilen ve kendisine meşru olmadığı mesajı verilen kesimleri kapsamaktadır (Foulquie, 1998, 75). Ötekileștirilen kesimler arasında kadınlar, eşcinseller, mülteciler, azınlıklar gibi farklı gruplar yer almakta olup; ötekileștirme dilsel pratikler üzerindeki etkisi ile ideolojinin bir aracı olarak nefret söyleminden nefret suçuna kadar uzanan süreçte önemli bir işlev yerine getirmektedir.

Temelde ideolojiler dil ekseninde şekillenmekte olup; dili kullananların seçtikleri sözcükler, konuşma biçimleri söylemin oluşumunda temel bir etmendir. Ancak; söylemle ilgili olarak metnin her şey önce bir yapı olduğu ve yapısal örgüsüne ek olarak kendisini çevreleyen dış gerçekliklerle bağlantılı bir biçimde ele alınması gerekliliği üzerinde önemle durulması gereken bir noktadır (İnceoğlu ve Çomak, 2009, 19-35). Örneğin, kitle iletişim araçları aracılığı ile egemen söylemin bir ürünü olarak üretilen "haber", hakim ideolojinin "biz" tanımı üzerinden; ötekileştirilen gruplara yönelik olumsuz, alaycı ifadeler veya hakaret üretebilmektedir. $\mathrm{Bu}$ bağlamda, kitle iletişim araçlarında ötekileştirilen gruplar, kamu güvenliğini tehdit ederek potansiyel risk ve tehdit oluşturan kişiler olarak sunulabilmektedir (İnceoğlu, 2012, 13). Böylece; hakim ideoloji ekseninde şekillenen nefret söylemi, nefret suçuna giden sürecin temel çıkış noktasını oluşturan bir yapıya kavuşmaktadır. Hedef alınan gruplara duyulan tahammülsüzlük ve hoşgörüsüzlüğe bağlı olarak verilen “Toplumda size yer yok!” mesajı ile ötekileştirilen grup üyeleri pasifleştirilmektedir. Bu bağlamda, farklı kaynaklardan beslenerek ortaya çıkan nefret söylemi, ötekiye duyulan tahammülsüzlük ve hoşgörüsüzlük çerçevesinde kendini her daim öfke ve nefret dolu ifadelerle ortaya koymakta olup; zaman zaman normal ve mantıklı bile görünebilmektedir (İnceoğlu ve Çoban, 2014, 66). $\mathrm{Bu}$ bağlamda; ötekileştirme pratikleri ve nefret söylemi, gündelik konuşmalardan televizyon programlarına, atasözlerinden bir siyasetçinin söylemlerine kadar farklı alanlarda açık ve örtük bir biçimde karşımıza çıkabilmektedir. 
$\mathrm{Bu}$ süreçte, devletin ideolojik aygıtı olan medya, kendi gündemini yaratırken, toplumsal bağlamdan kopuk bir biçimde örtük veya açık olarak ırkçılık, etnik önyargl, yabancı korkusu gibi kavramlar üzerinden nefreti yeniden üreterek yaymaktadır. Kitle iletişim araçları, olumsuz ve alaycı ifadelerle ötekileştirdiği ve hedef haline getirdiği kesimlere yönelik önyargıları pekiştirmekte ve bu grupların kendilerini savunmasız hissetmelerine yol açmaktadır. Bu durum, bir yandan kişinin belli bir gruba aidiyeti yüzünden küçük düşürülmesine yol açmakta olup; bir yandan da nefret söylemi üreten zümreye güç atfetmesi açısından çift taraflı olarak zarar yaratmaktadır. Medyanın ötekileștirme pratiklerinden zarar gören ve ötekileștirilen gruplar arasında eşcinseller de yer almaktadır. İnceoğlu ve Çoban (2014) "Ötekileştirme Sürecinde Medyanın Yeri" isimli çalışmalarında çeşitli gazetelerde yer alan “Gay Bardan Çıkıp Gasp Yaptılar!”, "Eşcinsel Öğretmen İşten Kovuldu!"başlıkları üzerinden cinsel yönelimleri nedeni ile eșcinselleri yönelik nefret söylemi üretildiğini ve yayıldığını ortaya koymuştur. Örneklerde görüldüğü üzere; hukuken bir suç olan "gasp" fiili örtük bir biçimde "gay" olmakla ilişkilendirilmektedir. Eşcinsel öğretmenin işten kovulması da kişinin cinsel tercihi sebebi ile işten çıkarılmasını hak ettiği savı üzerinden mağdurun hakkını ortadan kaldıran, suçu haklılaştıran ve meşrulaştıran bir ifade olarak karşımıza çıkmaktadır. Ayrıca, İnceoğlu ve Çoban'ın inceledikleri gazete manşetlerinde homofobik bir söylem temelinde karşımıza çıkan “Travesti Dehşeti!”, “Ters İlişki Teklif Etti, Öldürdüm!”, biçimindeki ifadelerle eşcinsel bireylere yapılan saldırıların meşru bir zemine taşındığını vurgulamıştır. $\mathrm{Bu}$ bağlamda, medya eşcinsel bireylerle ilgili haberleri "cinsel içerikli ve toplumsal ahlaka aykırı" olarak; eșcinsel bireyleri ise "sapkın" ve "canavar" olarak sunmaktadır (İnceoğlu ve Çoban, 2014, 66). Alanyazında, eşcinselliğin medyada sunumuna yönelik olarak gerçekleştirilen çeşitli araştırmalar bulunmakta olup; Gelgeç ve Öktem (2008) yazılı basında eşcinselliğin sunumunu analiz ettikleri çalışmalarında eşcinselliğin eğlencelik bir olgu olarak görüldüğü ve seks işçiliği ile ilişkilendirildiği sonucuna ulaşmıștır (Gelgeç ve Öktem, 2008). İnternet gazetelerinde eșcinselliğin sunumuna yönelik bir diğer çalışma Kılıç (2011) tarafından Sabah ve Hürriyet gazetelerine yönelik gerçekleştirilmiş olup; araştırma bulguları eşcinsellerle ilgili haberlerin kișilerin cinsel yönelimi üzerine odaklandığı sonucunu ortaya koymuștur. Ayrıca, araştırmada incelenen haberlerde eşcinsellerin karşılaştıkları ayrımcılık sorunlarına yer verilmediği ve eşcinsellerin eğlencelik bir nesne olarak sunulduğu sonucunu da ulaşılmıştır. Kılıç'ın çalışmasında tespit edilen bir diğer önemli bulgu ise; eşcinsellere yönelik şiddet eylemlerinin cinsel yönelimlerine bağlı olarak medya tarafından meşrulaştırılması olmuştur (Kılıç, 2011). Bu bağlamda, cinsel yönelimler ekseninde sürekli olarak egemen ideolojiyi yeniden üreten kitle iletişim araçları eşcinsellere yönelik doğrudan ve dolaylı olarak nefret söylemi üretmekte ve eşcinsellerin toplumsal yaşamda karşılaşabileceği ayrımcı davranışlara ve nefret suçlarının oluşumuna olanak sağlamaktadır.

Alanyazında, ABD ve Avrupa'da homofobi ve şiddet arasındaki ilişkiye yönelik olarak gerçekleştirilen çok sayıda çalışma; homofobik şiddetin nefret suçları ile bağlantılı olarak incelenmesinin gerekliliği üzerinde yoğunlaşmaktadır. Türkiye'de ise; homofobik tutumlar, eșcinsel bireylere yönelik sistematik ayrımcılık ve ayrımcılığın sonuçları ile ilgili olarak az sayıda akademik çalışma ve araştırma bulunmaktadır. Bunlardan biri, 2011 yılında KAOS GL derneği tarafından eşcinsel bireylerle gerçekleştirilen görüşmeler ve anket çalışması olup; araştırma bu kişilerin cinsel yönelimleri nedeni ile günlük hayatta maruz kaldıkları ayrımcı 
davranış biçimlerini ortaya koymaya çalıșmıștır. Göregenli ve Karakuş tarafından analiz edilen araştırma verileri, katılımcıların \%80'e yakınının hayatlarında en az bir defa homofobik bir ayrımcılık deneyimi yaşadığını ve katılımcıların yarısından fazlasının cinsel kimliğinden ötürü ayrımcılığa veya şiddete maruz kalmaktan korktuğu sonucunu ortaya koymuştur (Göregenli, 2011a, 4, 7-8, 50-51). Türkiye'de resmi ideolojik söylem çerçevesinde eşcinselliğe yönelik görüş incelendiğinde ise; hukuki olarak eşcinselliğin hiç bir zaman suç sınıfına girmediği ancak psikolojik bir rahatsızlık olarak görüldüğü sonucuna ulaşılmaktadır. Ayrıca, kamusal alanda askere gitme süreçlerinde eşcinsel bireylerin psikolojik hastalıkları varmış gibi muamele görmesi; cinsel yönelimleri sebebi ile işten çıkarılması, eğitim haklarının kısıtlanması ya da sosyal çevrelerinde küçük düşürülmesi gibi örneklere sıkça rastlanmaktadır. Resmi makamlar açısından ise eşcinselliğe yönelik açıklamaların bilimsel dayanaklara bağlı olmadan gerçekleștirildiği görülmektedir. Bu duruma örnek olarak, 2009 yılında gerçekleştirilen IV. Din Şurası kararlarında eşcinselliğin "cinsel davranış bozukluğu" olarak tanımlanması ve İslam'ın eşcinsellik karşıtı duruşunun değişmeyeceğine yönelik açıklama ile Avrupa Konseyi'nin farklı ülkelerin aileden sorumlu bakanlarına yönelik toplantısında; Türkiye Bakanı'nın eșcinsel evlilik ve ebeveynliğin kabul edilemeyeceği yönündeki beyanatı verilebilir. Hükümet yetkilileri ya da politikacıların konuyla ilgili açıklamalarına örnek olarak ise; Kadın ve Aileden Sorumlu Devlet Bakanı'nın eșcinselliği tedavi edilmesi gereken bir hastalık olarak gördüğünü açıklaması; bir belediye başkanın Türkiye'de asla eşcinsel bir belediye başkanının olmamasını umut ettiğini dile getirmesi, hükümet yetkilileri tarafından Hollanda'da bir Türk ailenin çocuğuna eşcinsel bir çiftin koruyucu aile olması sonucu gerçekleştirilen olumsuz söylemler verilebilir. Bu açılamaların tamamı kitle iletişim araçlarına da basın ahlakına uymayacak bir biçimde yansımakta olup; eşcinsel bireylerde korku ve güvensizlik oluşturmakta ve toplum içerisinde eşcinsellere karşı olumsuz duyguları beslemektedir. (Yüksel, 2011 ve Bianet, 2015) Bu bağlamda, resmi ideolojik söylem çerçevesinde kamusal alanda devamlı olarak üretilen eşcinsellere yönelik nefret söylemi; eşcinsel bireylerin toplumsal hayat içerisinde sözel ve fiziksel ayrımcılık içeren davranışlara maruz kalmalarına ve ileri aşamalarda nefret suçlarının işlenmesine olanak sağlamaktadır.

\section{Bir Yeni Medya Platformu Olarak Twitter ve Nefret Söyleminin Yayılımı}

Kitle iletişim araçları aracılığı ile belirli azınlık ya da gruplara yönelik nefret söylemi yaygın olarak üretilmektedir; ancak son on beş yıllık dönem içerisinde İnternet'in gelişimi ile birlikte kullanıcıların da dahil olduğu aktif bir iletişim alanının meydana gelmesi nefret söyleminin üretim biçimlerini de değiştirmiştir (Cammaerts, 2009, 3-5). Günümüzde yeni medya, kullanıcların medya içeriği üretebildiği, özelleştirebildiği, yayabildiği ve yorumlayabildiği bir alan olarak; medya tüketicisi durumunda olan alıcının iletişim sürecine aktif bir biçimde dahil olmasına neden olmuştur (Jenkins, 2002). Kullanıcıların yeni medya ortamlarında aktif olarak hareket etmesinde; İnternet kullanıcıları tarafından Twitter, Facebook ve Youtube gibi yeni medya platformlarında, forumlarda ve bloglarda üretilen çeşitli iletilerin bütününden oluşan kullanıcı türevli içeriğin etkisi büyüktür (Comninos, 2013, 5). OECD tarafından, İnternet üzerinde açık erişime sahip ve profesyonel içerik üretim pratikleri dışında oluşturulan içerik olarak tanımlanan kavramın ortaya çıkması ile birlikte; enformasyon üretim, dağıtım ve paylaşım süreçleri ciddi bir değişim geçirmiştir. Kullanıcının kendini daha bağımsız, yaratıcı ve katılımcı bir biçimde ifade etmesine imkan sağlayan kullanıcı türevli içerik; özgür enformasyon akışı ve 
ifade özgürlügü alanının genişlemesinde etkili olmuştur (OECD, 2007,8 ve OECD, 2008,6). Ancak, kullanıcı türevli içeriğin ortaya çıkması nefret söylemi üretim süreçlerine yönelik kontrolü ortadan kaldırırken; nefret söyleminin yayılımını hızlandırabileceğine yönelik endișeler mevcuttur (George and Scerri, 2007, 6-7).

Kullanıcı türevli içeriğin üretildiği ve dağıtıma girdiği önemli yeni medya platformlarından bir tanesi de Twitter olup; 2017 yılının son çeyreğinde dünya çapında kullanıcı sayısı 255 milyonun üzerine çıkmıştır (Statista, 2017). Twitter, kullanıcıların birbirine maksimum 140 karakter uzunluğunda mesajlar göndermesine izin vererek iletişim kurmalarını sağlayan ücretsiz bir mikroblogging uygulaması olarak hayata geçmiştir. Mobil iletişim teknolojilerinin ilerlemesine bağlı olarak etki alanı giderek genişleyen Twitter uygulaması ile kullanıcılar çeşitli aygıtlar üzerinden enformasyon paylaşımı gerçekleştirebilmekte olup; Kasım 2017 tarihinde karakter limiti 240'a çıkarılmıştır. Ayrıca ilk etapta sadece metin paylaşımına izin veren site zaman içerisinde video, fotoğraf gibi multimedya içeriğinin de iletilere eklenmesine izin veren bir yapıya kavuşmuştur (Akar, 2011,59, OpenUniversity, 2018, Twitter, 2017). Twitter üzerinde kullanıcılar bir konu veya mesajı kategorize etmek amacıyla "\#” sembolünü kullanmakta ve bu sembol bir işaretleme aracı yani "etiket" (hashtag) olarak adlandırılmaktadır. Twitter'da kullanıcılar arası iletişim; "bahsetme" (mention) olarak adlandırılan ve site üzerinde “@” işaretinin kullanıcı isimlerinin başına eklenmesi ile oluşan bir mesajlaşma biçimi ile sağlanmaktadır. Twitter üzerinde ileti akışını hızlandıran diğer bir özellik de; "paylaşım” (retweet) olarak adlandırılan ve bir kullanıcının iletisinin diğer kullanıcılar tarafından paylaşılmasına olanak tanıyan sistemdir (O’Reilly ve Millstein, 2009, 41-47). Twitter uygulaması, "tweet" olarak tanımlanan iletiler aracılığı ile pek çok kişinin aynı anda iletişim kurmasına olanak sağlayan bir yapıda dizayn edilmiştir. Böylece, Twitter kullanıcıları "takipçi” olarak güncellemelerinden haberdar olmak istedikleri diğer kullanıcıları izleyebilmekte, tweetlerini görebilmektedir (Boyd vd. 2010, 1-2). Ayrıca, Twitter'da kullanıcılar etiketler üzerinden takip etmedikleri kullanıcıların da tweetlerini korumalı tutmayı tercih etmemeleri koşulu ile herhangi bir konu hakkında paylaştıkları iletileri görebilmekte, paylaşabilmekte, beğenebilmekte, yorumlayabilmekte ve içerik üreticisi ile doğrudan iletişime geçebilmektedir. Bu temel özelliklere ek olarak; Twitter üzerinde herhangi bir iletinin kolayca diğer sosyal medya sitelerinde ve web sitelerinde paylaşlabilmesi platformun etkileşim gücünü arttırmaktadır.

Sahip olduğu bu özellikler, Twitter'da herhangi bir etiketin dolaşıma sokulması ile nefretsöylemininhızlagenişalanayayılmasında etkiliolabilmektedir.Twitter,kullanım politikasında açıkça nefret söylemi içeren içeriğin dolaşımını yasaklamamıştır. Ancak; bazı durumlarda kullanıcılarını herhangi bir içeriğin zararlı ve uygunsuz olabileceği konusunda uyarmakta ve bu tarz içeriklerin paylaşımı konusunda sorumluluk kabul etmemektedir. Fakat, Twitter kendisine rapor edildiği durumlarda ayrımcılık ve nefret söylemi içeren iletileri dolaşımdan kaldırabilmektedir. Platformun bu uygulamasına örnek olarak kadınlara yönelik çevrimiçi nefret söylemi içeren iletilere yönelik düzenleme mekanizmalarını harekete geçirdiği "Kadın, Medya ve Hareket" (WAM) projesi verilebilir. Proje kapsamında, kadınlar nefret söylemine maruz kaldıkları çeşitli iletileri Twitter ile paylaşmış olup; işletme elde ettiği veriler doğrultusunda cinsiyet ayrımcılığına karşı politikasını düzenlemiştir (Gagliardone vd., 2015, 13-14, 29, 44). Ancak, dünya çapında 250 milyondan fazla kullanıcısı olan 
Twitter üzerinde her gün milyonlarca ileti dolaşıma girmekte olup; platform tüm iletilerin denetlenmesinin güçlüğü nedeni ile etnik, cinsel, dini ya da politik temelli nefret söyleminin kontrolsüzce yayılabildiği bir alan haline gelebilmektedir.

\section{Eşcinsellere Yönelik Nefret Söylemi İçeren İletilerin Twitter'da İncelenmesi}

$\mathrm{Bu}$ çalışmanın temel çıkış noktasını, Türkiye'de resmi ideolojik söylem ve kamusal alan içerisinde eșcinselliğin doğal olmayan bir cinsel yönelim olarak nitelendirilmesi sonucu oluşan homofobik nefret söyleminin, çok sayıda farklı kullanıcının birbiri ile anlık ve hızlı bir biçimde iletişim kurabildiği ve çok yüksek ileti akış hızına sahip bir mikroblog olan Twitter üzerinde üretim ve dağılım imkanı bulduğu savı oluşturmaktadır.

\section{Araştırmanın Amacı, Kapsamı, Örneklemi ve Sınırıııkları}

$\mathrm{Bu}$ çalıșma, Twitter üzerinde 15-30 Mayıs 2015 tarih aralığında "eşcinsel" etiketi içeren iletileri nefret söyleminin üretimi ve dağılımı açısından incelemeyi amaçlamaktadır. Araştırma nüfusunu; Twitter üzerinde yer alan "eșcinsel" etiketi içeren ilgili tüm iletiler oluşturmaktadır. Örneklem içerisine 15-30 Mayıs 2015 tarihleri arasında “\#eşcinsel” etiketi içeren Türkçe tweetler dahil edilmiştir. Bu zaman diliminin tercih edilmesindeki temel amaç; Social Bakers 2015 verilerine göre \# eşcinsel etiketi içeren iletilerin sayısal olarak en fazla olduğu dönem olmasıdır. Ayrıca, \#LGBT (Lezbiyen, gay, transeksüel, biseksüel) etiketi içeren iletiler, Alacaoğlu (2013)'den belirttiği üzere Türkiye'de kendi cinsine karşı bir cinsel yönelim içerisinde olan bireyleri tanımlamak amacı ile "eşcinsel" sözcüğünün kullanılması nedeni ile örneklem dışında brrakılmıştır.Araştırma nesnesi olarak Türkiye'de "We are Social" araştırma platformunun 2015-2017 yılı istatistiklerine göre en çok kullanılan mikroblog uygulaması olan Twitter belirlenmiştir.

\section{Araştırmanın Yöntemi ve Araştırma Soruları}

Çalışma kapsamında 15-30 Mayıs 2015 tarih aralığında Twitter'da yer alan "\# eşcinsel" etiketli tweetler içerik analizi yöntemi ile incelenmiştir. Krippendorf, içerik analizi yöntemini tekrarlanabilir ve geçerli anlamlar çıkarmaya yönelik bir araştırma tekniği olarak tanımlanmaktadır. Teknik boyutu ile içerik analizi özel prosedürlerden oluşmakta olup; araştırmacını tekniğine, içgörüsüne ve konuya göre değişim gösterebilmektedir. Gösterdiği bu çeşitliliğe rağmen bilimsel bir yöntem olarak kabul edilen içerik analizinde sonuçlar güvenilir ve verilerin yorumlanabilir olması beklenmektedir (Krippendorff, 2003, 18-19). İçerik analizi, iletişimin görünen veya yazılı içeriğinin objektif, sistematik ve nicel bir yöntemle belirlenmesidir (Berelson, 1952, 56). Bu bağlamda, içerik analizi kodlama tablosu, araştırma sorularına cevap verecek biçimde İnceoğlu ve Çoban (2014), Kılıç (2011), Gelgeç ve Öktem (2008)'in eşcinsellere yönelik medyada nefret söyleminin sunum biçimlerine yönelik araştırmaları temel alınarak oluşturulmuş olup; iletiler konu, kaynak, nitelik, biçim, etkileşim ve ayrımcı ifadelerin varlığı ana kategorilerine bağlı olarak irdelenmiştir. Araştırmanın güvenilirliği ve geçerliliğini sağlamak için incelenen kategorilere "diğer" değişkeni eklenerek hatalar engellenmeye çalışılmıştır ve kodlama süreci Krippendorf ve Berelson'un tekrara dayanan içerik analizi anlayışına bağlı olarak gerçekleştirilmiştir. Bu bağlamda, araştırmada objektif sonuçlara ulaşmak amacı ile iletiler araştırmacı tarafından iki defa kodlanmış olup; araştırmanın geçerlilik düzeyi \%88,6 olarak hesaplanmıştır. Araştırmanın temel soruları ise şu şekilde yapılandırılmıştır: 
1. İncelenen “\#eşcinsel” etiketine sahip iletiler, konu bazında nasıl bir dağılım göstermektedir?

2. İncelenen "\# eşcinsel" etiketine sahip iletiler, kaynak bazında nasıl bir dağılım göstermektedir?

3. İncelenen "\# eşcinsel" etiketine sahip iletiler nitelik (iletilerin olumlu, olumsuz, nötr olması) bazında nasıl bir dağılım göstermektedir?

4. İncelenen “\#eşcinsel” etiketine sahip iletilerde, eşcinsellere yönelik örtük ve açık ayrımcı ifadeler mevcut mudur? Eğer mevcut ise; örtük ve açık ayrımcı ifadeler oransal bazda nasıl bir dağılım göstermektedir?

\section{Araştırmanın Bulguları}

$\mathrm{Bu}$ araştırma kapsamında Twitter'da; 15 Mayıs 2015- 30 Mayıs 2015 tarihleri arasında "\# eşcinsel" etiketi içeren toplam 485 iletiye ulaşılmıștır. Bu iletiler konu, iletiyi oluşturan konu, kaynak, nitelik, örtük ve açık ayrımcı ifadelere yer verilme durumu, biçim ve etkileşim değişkenleri açısından irdelenmiştir

Tablo 1: Twitter Üzerinde "Eşcinsel" Hashtag'i İçeren İletilerin Konu Bazında Dağımı

\begin{tabular}{|l|c|c|}
\hline $\begin{array}{l}\text { Twitter Üzerindeki \#Eşcinsel Hashtagi } \\
\text { İceren İletilerin Konu Bazında Dağılımı }\end{array}$ & Sayı & Oran \\
\hline Toplumsal yaşam konulu iletiler & 51 & $\% 10,5$ \\
\hline Siyaset konulu iletiler & 392 & $\% 80,82$ \\
\hline Spor konulu iletiler & 6 & $\% 1,2$ \\
\hline Adli vaka konulu iletiler & 9 & $\% 1,8$ \\
\hline $\begin{array}{l}\text { Eşcinsel hakları için eylem, açıklama } \\
\text { ve gösteriler hakkında iletiler }\end{array}$ & 3 & $\% 0,6$ \\
\hline $\begin{array}{l}\text { Eşcinsellik karşıtı eylem, açıklama } \\
\text { ve gösteriler hakkında iletiler }\end{array}$ & 3 & $\% 0,6$ \\
\hline Sağlık konulu iletiler & 1 & $\% 0,2$ \\
\hline Din konulu iletiler & 18 & $\% 4,28$ \\
\hline Sanat konulu iletiler & 0 & $\% 0$ \\
\hline Diğer iletiler & 0 & $\% 0$ \\
\hline Toplam ileti & 485 & $\% 100$ \\
\hline
\end{tabular}

Tablo 1'de görüldüğü üzere, \#eşcinsel etiketi içeren iletilerin konu bazında dağılımında ilk sırada \%80,82'lik oranla siyaset, ikinci sırada ise $\% 10,5$ 'lik oranla toplumsal yaşam kategorisi gelmektedir. Üçüncü sırada ise \%4,28'lik oranla din kategorisinde yer alan iletiler yer almaktadır. Araștırma döneminde siyaset kategorisinde çok sayıda iletinin tespit edilmesinin temel sebebi, 7 Haziran 2015 tarihinde yapılmış olan milletvekili seçimleridir. Eşcinselliğin bir yan unsur olarak kodlandığı siyaset bağlamında ele alınabilecek iletilerin yoğunluk göstermesinin nedeni ise; bir siyasal partinin milletvekili adaylarından birinin eşcinsel olmasıdır. Bu aday, diğer siyasi partilerin destekçileri tarafından cinsel tercihi nedeni ile eleștirilmiştir. Bu eleştiriler, cinsel içerikli nefret söyleminin dolaşıma girmesine izin verecek bir biçimde açık ve örtük ayrımcı ifadeler ekseninde şekillenmiştir. Ayrıca bu dönemde siyaset kategorisinde yer alan iletilerin sayısal olarak yoğunlukta çıkması; resmi ideolojik söylem ve kamusal alan içerisinde eşcinselliğin doğal olmayan bir cinsel yönelim olarak nitelendirilmesi sonucu eșcinsel bir bireyin milletvekilli adayı olarak siyasal temsiliyet mekanizmalarının içerisinde yer alması sonucu ortaya çıkan direnç mekanizmaları ile bağlantılı olarak değerlendirilebilir. Ayrıca, siyaset kategorisinde yer alan iletilerin 
sayısal olarak fazla olması; Foucault'un iktidarın beden üzerinde tahakkümü yaklaşımı çerçevesinde eşcinsel bireylerin iktidar alanında dışlanması bazında yorumlanabilir. Bu dönem içerisinde, en yüksek ikinci oransal dağılıma sahip olan toplumsal yaşam kategorisinde yer alan iletilerin ise; eşcinsel evliliklere yurt dışında izin verilmesi konusu ve Türkiye’ye yansımaları biçiminde şekillendiği görülmektedir. $\mathrm{Bu}$ kategoride yer alan iletilerin sayısal fazlalığ alanda farklı cinsel yönelimlerin yadsınması sonucu devlet tarafından geçerliliği olan resmi bir ilişki biçimi olan evlilik hakkının eşcinsellere verilmesine yönelik karşılıklı direnç noktaları etrafında şekillendiği biçiminde değerlendirilebilir. Din kategorisinde yer alan iletiler ise; Hristiyanlığın Katolik mezhebinin merkezi olan Vatikan'ın eşcinsel evlilikleri olumsuz bir biçimde değerlendirip; ötekileştirilmesi üzerine yoğunlaşmaktadır. Bu bağlamda din ve toplumsal yaşam kategorisinde eşcinsellik konulu iletilerin sayısal olarak fazlalığı; eşcinsel bireylere yönelik ötekileștirme pratiklerinin Althusser'in içerisine din ve gelenek unsurlarını dahil ettiği devletin ideolojik aygıtları aracılığı ile hakim ideolojinin meşrulaştırılması çerçevesinde değerlendirilebilir.

İnceleme döneminde, cinayet, fuhuş, hırsızlık gibi eşcinsel kimlikle doğrudan ilişkilendirilen suçları içeren adli vaka kategorisinde ele alınabilecek, eşcinsel haklarına yönelik doğrudan savunuculuk kategorisinde değerlendirilebilecek ya da eşcinsellik karşıtı bir özellik taşıyan iletilere sınırlı sayıda rastlanmıştır. Ayrıca araştırma döneminde, sağlık ve spor kategorilerinde de oransal olarak az sayıda iletiye ulaşılmış olup; bu durum toplumsal yaşam içerisinde eşcinsel bireylerin görünürlüklerinin sınırlı olması ile bağlantılı olarak değerlendirilebilir.

Tablo 2: Twitter Üzerinde "Eşcinsel" Hashtag'i İçeren İletilerin Kaynak Bazında Dağımı

\begin{tabular}{|l|c|c|}
\hline Twitter Üzerindeki \#Eşcinsel Hashtagi İçeren İletilerin Kaynak Bazında Dağılımı & Sayı & Oran \\
\hline Eşcinsel birey/grup kaynaklı iletiler & 15 & $\% 3$ \\
\hline Eşcinsel haklarını savunan aktivistler kaynaklı iletiler & 2 & $\% 0,4$ \\
\hline Sanat, spor veya iş dünyasında tanınmış kişi kaynaklı iletiler & 1 & $\% 0,2$ \\
\hline Tıp alanında uzman kaynaklı iletiler & 0 & $\% 0$ \\
\hline Eşcinsellik karşıtı birey ya da gruplar kaynaklı iletiler & 0 & $\% 0$ \\
\hline Siyasi bir parti temsilcisi/lider kaynaklı iletiler & 5 & $\% 1$ \\
\hline Kamu kurumu temsilcisi kaynaklı iletiler & 0 & $\% 0$ \\
\hline Eşcinsellikle ilgili yorum yapan kullanıcılar kaynaklı iletiler & 365 & $\% 75,25$ \\
\hline Kitle iletişim araçları kaynaklı iletiler & 97 & $\% 20,15$ \\
\hline Diğer iletiler & 0 & $\% 0$ \\
\hline Toplam ileti & 485 & $\% 100$ \\
\hline
\end{tabular}

Tablo 2'de görüldüğü üzere, Twitter'da “\#eşcinsel” etiketi içeren iletilerin kaynak açısından dağılımı incelendiğinde, ilk sırada \%75,25'lik oranla eşcinsellikle ilgili yorum yapan kullanıcıların yer aldığı görülmektedir. İncelemede, özellikle siyaset kategorisinde yer alan iletilerin dağılımı açısından, farklı siyasal görüşlerde olduğunu Twitter hesaplarıda ve iletilerinde belirten kullanıcıların eşcinsel bir bireyin milletvekili adaylığı üzerinden homofobik nefret söylemi içeren iletileri dolaşıma soktuğu sonucuna ulaşılmıştır. Buna karşın, araştırma kapsamında, eşcinsel haklarını kişisel özgürlükler kapsamında ele alıp savunan bireysel Twitter kullanıcılarının da mevcut olduğu tespit edilmiștir. İletilerin kaynak bazlı dağılımda ikinci sırada ise $\% 20,15$ 'lik oranla geleneksel kitle iletişim araçlarının yeni medya üzerindeki uzantıları olan Twitter hesaplarından eșcinsellik konusunda paylaşılan iletiler yer 
almaktadır. Üçüncü sırada ise \%3'lük bir oranla KAOS GL, Lambada İstanbul gibi eşcinsel grupların temsilciliğini üstlenen STÖ'lerin resmi Twitter hesaplarından yapılan paylaşımlar veya eşcinsel bireylerin iletileri bulunmaktadır. Bu paylaşımlar arasında, bir siyasal parti tarafından milletvekili adayı olarak gösterilen eşcinsel bir bireyin; cinsel kimliği nedeni ile kendisine yönelik hakaret içeren iletilere karşı kendini savunduğu iletiler ön plana çıkmaktadır. İletilerin kaynağa göre dağılımında; incelenen tarih aralığında bir kamu kurumu temsilcisinin veya tıp alanında uzman bir kişinin doğrudan oluşturduğu bir iletiye rastlanmamıştır. Ayrıca, inceleme döneminde kanaat önderleri olarak ele alabileceğimiz iş dünyası, spor veya sanat alanında tanınmış kişilerin eşcinsellik ile ilgili siyasal içerikli tartışmalara dahil olmadığı tespit edilmiştir. Bu durum eşcinselliğin, resmi söylem çerçevesinde ötekileştirilen bir cinsel yönelim olması ile ilişkili olarak değerlendirilebilir. Nefret söyleminin dolaşımı açısından araştırma verileri incelendiğinde ise; doğrudan eșcinsellik karşıtı bir grubun oluşturduğu iletilere rastlanmamıștır. Bu nedenle araștırma bulguları, üçüncü tekil şahıslar olarak eşcinsellikle ilgili ayrımcı ve ötekileștirici iletiler üreten ve yayan kullanıcıların mevcut olduğunu göstermekle birlikte, sistematik bir örgütlenme ekseninde yaratılan nefret söyleminin varlığını kanıtlayan özellikte iletilere rastlanmamıștır.

Tablo 3: Twitter Üzerinde "Eşcinsel" Hashtag'i İçeren İletilerin Nitelik Bazında Dağımı

\begin{tabular}{|l|c|c|}
\hline $\begin{array}{l}\text { Twitter Üzerindeki \#Eşcinsel Hashtagi } \\
\text { İçeren İletilerin Nitelik Bazında Dağılımı }\end{array}$ & Sayı & Oran \\
\hline Olumlu iletiler & 42 & $\% 8,65$ \\
\hline Olumsuz iletiler & 419 & $\% 86,4$ \\
\hline Nötr iletiler & 24 & $\% 4,95$ \\
\hline Diğer iletiler & 0 & $\% 0$ \\
\hline Toplam İleti & 485 & $\% 100$ \\
\hline
\end{tabular}

Tablo 3'de görüldüğü üzere; Twitter'da "eșcinsel” etiketi içeren iletilerin niteliğe göre dağılımında ilk sırada \%86,4'lük oranla olumsuz iletilerin, ikinci sırada ise \%8,65'lik oranla olumlu iletilerin geldiği görülmektedir. Son sırada ise \%4,95'lik oranla nötr iletiler yer almaktadır. Nefret söylemine gidebilecek nitelikte yer alan olumsuz iletilerin dağılımına baktığımızda genel olarak siyaset kategorisinde yer alan iletiler içerisinde yer aldıkları görülmektedir. Nötr ve olumlu iletiler ise eşcinsellerin toplumsal yaşamlarını doğrudan etkileyen evlilik, birlikte yaşam, çalışma koşulları gibi alanlarda yaşanan gelişme ve değişimlerle ilgilidir.

Tablo 4: Twitter Üzerinde "Eşcinsel" Hashtag'i İçeren İletilerde Ayrımcı/Ötekileștirici Ífadelerin Dağılımı

\begin{tabular}{|l|c|c|}
\hline $\begin{array}{l}\text { Twitter Üzerindeki \#Eşcinsel Hashtagi İçeren Ayrımcı } \\
\text { İfadelere Yer Verilme Oranı Ekseninde Dağıımı }\end{array}$ & Sayı & Oran \\
\hline Ayrımcı ifadeler içeren iletiler & 271 & $\% 55,87$ \\
\hline Örtük ayrımcı ifadeler içeren iletiler & 185 & $\% 38,14$ \\
\hline Açık Ayrımcı ifadeler içeren iletiler & 86 & $\% 17,73$ \\
\hline Ayrımcı ifadeler içermeyen iletiler & 214 & $\% 44,13$ \\
\hline Diğer iletiler & 0 & $\% 0$ \\
\hline Toplam İleti Sayısı & 485 & $\% 100$ \\
\hline
\end{tabular}

Tablo 4'de görüldügü üzere, Twitter'da "eșcinsel" etiketi içeren iletilerde ayrımcı ifadeler içeren bir söylemin varlığı baskın bir biçimde kendini göstermektedir. İletilerin dağılımında, \%55,87'lik bir oranda ayrımcı ifadelere yer verilme oranı 
ilk sırada yer almaktadır. Tweetlerin örtük ve açık ayrımcı ifadeler ekseninde dağılımında, \%38,14'lük oranla örtük ayrımcı ifadelerin, \%17,73'lük oranla açık ayrımcı ifadelere göre daha fazla yer aldığı görülmektedir. İletilerin dağılımında ise eşcinsellere yönelik ayrımcı bir söylemin yer almadığı iletilerin oranı ise \%44,13'tür. Bu bağlamda, eșcinsellere yönelik örtük ayrımcı ifadelere örnek olarak; "Eşcinsel aday göstermelik! Ayrıca eşcinsel aday tabanıyla çelişiyor!", "Eşcinsel aday gösteren partilerin eșcinsel adayları hakkında tepkiler büyüyerek devam ediyor!", "Eşcinsel evlilik kanunla resmi hale getirilecekmiş! Size de bu yakıșır!", "Eşcinsel evliliğin yasal olması insanlık için yenilgi!", "Eşcinsel adaya oy vermeyi düşünenler bir daha düşünün, Rabbim bunun hesabını sormaz mi ???", "Vatikan'dan eşcinsel evliliğe sert tepki!", "Şu partinin eşcinsel aday fotolarından midemiz bulandı loo ..", "Bu partinin azınlıklara dayalı coğrafi özerklik programında tüm eșcinsel ve travestileri de bir yerde toplayıp özerklik verme fikri var mı?”, "Tamam eşcinsel olma demiyorum ol git ne oluyosan ol. Ama hobi olarak ol yine bir karın olsun altın bilezik. Hobi olarak yine eșcinsel ol” iletileri örnek olarak gösterilebilir. Bir cinsel kimlik olarak eşcinselliği örtük bir biçimde ötekileștiren bu iletiler, doğrudan nefret söylemi oluşturmamakla birlikte ayrımcılığı körüklemektedir. Örtük olarak ileti dili içerisinde kullanılan ayrıştırıcı ifadeler ise; dolaylı oluşturulan nefret söylemi ekseninde eşcinsel bireyleri dışlamaktadır. Açık bir biçimde ayrımcı ifadelerin yer aldığı tweetlere örnek olarak " 3-5 İ**enin oyunu alacağım diye bu kadar eşcinselleşme, eşcinsel partisi oldun!", "Eşcinsel milletvekili adayının skandal fuhuş görüntüleri ortaya çıktı!", "Her itliğinizi anladık da Müslüman bir ülkede; eşcinsel aday ne demek, eşcinsel evlilik ne demek?", "Eşcinsel sapıklara oy vermeyeceğiz!", "Eşcinsel adayı olan, şer yuvasına çalışan şakirtlere ne denir?”, "Sodom ve Gomore, ve onları eşcinsel adayları, hasta Toplumlar" iletileri verilebilir. Ayrıca, açık ayrımcı ifadelerin yer aldığı tweetler fotoğraflarla da desteklenmiş olup; Tweetlerde, söylemin etki gücünü görsel ile desteklemek amaçlı eşcinsel milletvekili adayının fotoğrafları ve aday olduğu parti yöneticilerinin fotoğrafları bilgisayar programları ile değiştirilmiştir. İletilerde kullanılan açık ve örtük ayrımcı ifadelerde göze çarpan en önemli nokta, eşcinsellere yönelik homofobik nefret söyleminin irksal ve dinsel karşıtlıklar ekseninde temellendirilmesidir. $\mathrm{Bu}$ durum, egemen söylemin ideolojik bir taşıyıcısı olarak dinin; müslüman bir ülkede eşcinsel bir bireyin siyasal temsil mekanizmalarına dahil olamaması için geçerli bir argüman olarak sunulması ve eşcinsel bir bireyi aday gösteren partinin Güneydoğu kökenli olması bağlamında homofobik nefret söylemine ırkçı nefretin köken oluşturması biçiminde değerlendirilebilir. 
Tablo 5: Twitter Üzerinde "Eșcinsel" Hashtag'i İçeren İletilerin Biçimsel Bazda Dağılımı

\begin{tabular}{|l|c|c|}
\hline $\begin{array}{l}\text { Twitter Üzerindeki \#Eşcinsel Hashtagi İçeren } \\
\text { İletilerin Biçimsel Bazda Dağıımı }\end{array}$ & Sayı & Oran \\
\hline Metin içeren iletiler & 485 & $\% 100$ \\
\hline Rasyonel çağrışım kullanılan metin içeren iletiler & 85 & $\% 17$ \\
\hline Duygusal çağrışım kullanılan metin içeren iletiler & 400 & $\% 83$ \\
\hline Metinlerin toplam kelime sayısı & 6494 & - \\
\hline Görsel içeren iletiler & 152 & $\% 31,34$ \\
\hline Bilişsel çağrışım kullanılan görsel içeren iletiler & 21 & $\% 4,32$ \\
\hline Duygusal çağrışım kullanılan görsel içeren iletiler & 131 & $\% 27,02$ \\
\hline Video içeren iletiler & 20 & $\% 4,12$ \\
\hline Bilişsel çağrışım kullanılan video içeren iletiler & 6 & $\% 1,2$ \\
\hline Duygusal çağrışım kullanılan video içeren iletiler & 14 & $\% 2,92$ \\
\hline Internet/sosyal medya sitelerine link içeren iletiler & 143 & $\% 29,48$ \\
\hline Diğer iletiler & 0 & $\% 0$ \\
\hline Toplam ileti & 485 & $\% 100$ \\
\hline
\end{tabular}

Tablo 5'da görüldügüü üzere, Twitter'da "eşcinsel" etiketi içeren iletiler biçimsel açıdan incelendiğinde ilk sırada \%100'lük bir oranla metin; ikinci sırada \%31,34'lük oranla görsel; üçüncü sırada ise \%29,48'lik oranla link kategorisinin geldiği görülmektedir. Çağrışım özellikleri açısından iletiler analiz edildiğinde ise metin, görsel, video kategorilerinde; duygusal çağrıșım kullanımının rasyonel çağrıșım kullanımına göre daha yoğun olduğu görülmektedir. İletilerde kullanılan rasyonel çağrışımlar, alıcılar üzerine etkiyaratmak için mantıklı gerekçelerin ortaya konulması anlamına gelmekte olup; duygusal çağrışımlar korku, mutluluk, nefret, sevgi gibi hislerden beslenerek alıcıların duygu durumları üzerinde etki yaratmayı amaçlamaktadır. Bu bağlamda, incelenen iletilerde duygusal çağrışım içeren mesajların sayısal fazlalığı, bireylerin özel hayatlarının bir parçası olan cinsel tercihleri nedeni ile ötekileştirilmesi sonucu oluşan nefret söyleminin özünde rasyonel temellere oturtulamayacağ gerçeği ile bağlantılı olarak değerlendirilebilir. Ayrıca, Twitter diğer sosyal medya bileşenleri ile bağlantılı bir mikroblog olarak; kullanıcı türevli içeriğin yayılmasına imkan tanımaktadır ve eşcinsel haklarının savunuculuğu açısından görsel ve işitsel olarak zengin içeriğin oluşmasına izin verecek bir yapıdadır. Dolayısıyla Twitter'ın bu özellikleri farklı cinsel yönelimlerin kamusal alanda kabülü açısından hak savunuculuğu yapılmasını kolaylaştırabilir. Ancak, araştırma sonuçlarında eşcinsellik olgusuna yönelik olumsuz ve ayrımcllık içeren iletilerin yüksek oranda tespit edilmesi; Twitter'ın etkileşimsellik özelliğinin homofobik nefret söyleminin yayılması açısından araçsallaştırıldığı biçiminde değerlendirilebilir.

Tablo 6: Twitter Üzerinde "Eşcinsel" Hashtag'i İçeren İletilerin Etkileșim Bazında Dağılımı

\begin{tabular}{|l|c|}
\hline $\begin{array}{l}\text { Twitter Üzerindeki \#Eşcinsel Hashtagi İçeren } \\
\text { İletilerin Etkileşim Bazında Dağılımı }\end{array}$ & Sayı \\
\hline İletilerin toplam etkileşim sayısı & 15.484 \\
\hline İletilerin toplam paylaşım sayısı (Retweet) & 9226 \\
\hline İletilerin toplam beğeni sayısı (Favorite) & 6238 \\
\hline İletilere yapılan toplam yorumların sayısı & 20 \\
\hline İletilere yapılan toplam olumlu yorumların sayısı & 1 \\
\hline İletilere yapılan toplam olumsuz yorumların sayısı & 19 \\
\hline İletilere yapılan toplam nötr yorumların sayısı & 0 \\
\hline
\end{tabular}


Tablo 6'da görüldüğü üzere, inceleme döneminde Twitter'da "eşcinsel" etiketi içeren iletilerin toplam paylaşım (retweet) sayısı 9226, iletilerin beğenilme sayısı (favorite) 6238, paylaşılan iletilere yorum sayısı ise 20'dir. Yapılan yorumların ise sadece bir tanesi olumlu iken; geri kalan 19 tanesi olumsuzdur. Toplam iletilerin \%86'4'lük oranının olumsuz olduğu sonucuna bağlı olarak; nefret söyleminin dolaşımı açısından iletilerin paylaşım ve beğeni sayısının yüksek bir oranda olduğu görülmektedir. Günümüzde Twitter kullanıcılarının içeriğin üreticisi, dağıtıcısı ve kullanıcısı olduğu düşünüldügünde, eşcinsellere yönelik nefret söylemi sadece üretilmemektedir. Kullanıcılar, Twitter üzerinde "retweet" ederek nefret söylemini yaymakta; beğenerek ise meşrulaştırmaktadır.

\section{Sonuç ve Tartışma}

Geleneksel kitle iletişim araçlarının egemen söylemi meşrulaştıran yapısı bazı grupların kamusal alanda ötekileştirilmesine ve nefret söyleminin yayılmasına neden olmaktadır. Yeni medya araçlarının etkileşimli yapısı ise; iletişim sürecini içerisine alıcının da dahil olduğu çift yönlü bir boyuta getirerek; ifade özgürlüğü ve temsil açısından daha etkin bir alan yaratmıştır. Ancak, yeni medyanın anonimliği ve denetimden uzaklığı, nefret söyleminin dolaşıma girmesini kolaylaştırarak ifade özgürlüğü sınırlarını bulaştırmaktadır. Bu bağlamda, bir yeni medya platformu olarak Twitter üzerinde eșcinsellik temelli nefret söyleminin üretimi ve dağılımı incelemek amacıyla gerçekleştirilen bu araştırmada inceleme döneminde içerisinde homofobik nefret söyleminin üretildiği ve paylaşıldığı sonucuna ulaşılmıştır. Bu çalışma 2015 yılında gerçekleştirilmiş olup; 2016 ve 2017 yıllarında Twitter üzerinde nefret söylemi üretebilecek nitelikte \# eşcinselleriistemiyoruz, \# eșcinsellikyasaklansın gibi çeşitli etiketler dolaşıma girmiştir. Günümüzde ayrıca, bir içerik paylaşım platformu olan Instagram'a etiket takip özelliğinin eklenmesi bu alanı da nefret söyleminin dolaşımı açısından açık bir alan haline getirmektedir. Ayrıca, Facebook ve Youtube gibi yeni medya araçlarına yüklenen içerikler ya da yapılan kullanıcı yorumları ile eșcinsellik temelli nefret söylemi üretilebilmekte olup; bu araştırma farklı özelliklerdeki yeni medya platformlarında homofobik nefret söyleminin üretim ve dağıtım biçimlerinin incelenmesi açısından yol gösterici olabilir.

Bu bağlamda araştırma verileri temele alınarak; incelenen "\# eşcinsel" etiketine sahip iletilerin konu bazında nasıl bir dağılım gösterdiğine yönelik olarak oluşturulan araştırmanın birincil sorusu; iletilerin sayısal olarak siyaset, toplumsal yaşam ve din kategorilerinde incelenen diğer kategorilere göre daha fazla olduğu biçiminde cevaplanmıştır. Bu veriler, Foucault'un iktidarın beden üzerinde tahakkümü ve Althusser'in devletin ideolojik aygıtları yaklaşımlarına bağlı olarak; kamusal alanda sürekli olarak ötekileştirilen eşcinsel bireylere yönelik nefret söyleminin bir yeni medya platformu olarak Twitter üzerinde kolayca üretim ve dağıtım imkanı bulduğu biçiminde değerlendirilebilir. İncelenen “\# eşcinsel” etiketine sahip iletilerin kaynak bazında nasıl bir dağılım gösterdiğine yönelik olarak oluşturulan araștırmanın ikincil sorusu ise; sayısal olarak eșcinsellikle ilgili yorum yapan bireyler ve kitle iletişim kaynakları kategorilerinde incelenen diğer kategorilere kiyasla yoğunlaștığı biçiminde cevaplanmıştır. Ayrıca, inceleme döneminde; eşcinsel bireyler ya da bu alanda hak savunuculuğu yapan gruplar tarafından üretilen iletilerin sinırlı sayıda tespit edilmesi; bu dönem aralığında eşcinsel bireylerin yeni medya ortamlarında temsil gücünün zayıf olduğu ve farklı konulardaki iletilerde yan unsur olarak kodlandıkları biçiminde değerlendirilebilir. İncelenen “\#eşcinsel” etiketine sahip 
iletilerin eşcinsellere yönelik nefret söylemi çerçevesinde niteliksel olarak nasıl bir dağllımgösterdiğineyöneliküçüncü sorusu ise; olumsuz niteliktekiiletilerin olumluve nötr iletilere göre sayısal olarak fazla olduğu biçiminde cevaplanmıștır. Araştırmanın incelenen "\# eşcinsel" etiketine sahip iletilerin ayrımcı ifadeler içerme durumunu ve içeriyorsa açık ve örtük ayrımcı ifadelerin oransal dağılımın belirlenmesine yönelik dördüncü sorusu ise; ayrımcı ifade içeren iletilerin içermeyen ifadelere kıyasla sayısal olarak fazla olduğu ve bu iletilerde örtük ayrımcı ifadelerin sayısal olarak daha yoğun olduğu biçiminde cevaplanmıştır. Araştırmada elde edilen bu bulgular; araștırma sonucunda "\# eșcinsel" etiketine sahip iletilerin toplam paylașım sayısının "9226" ve beğeni sayısının ise "6238" olduğuna yönelik elde edilen veriler ile birlikte incelendiğinde; milyonlarca kullanıcısı olan bir mikroblog olarak Twitter üzerinde eşcinsellik temelli nefret söyleminin kolayca üretilip; dağıldığı biçiminde değerlendirilebilir. Bu bağlamda; kitle iletişim araçlarında ve kamusal alanda temsil imkanı bulamayan eşcinsel bireyler açısından Twitter alternatif bir kamusal alan yaratmaktan ziyade; gündelik hayatta karşılaşılan ayrımcılık pratiklerinin ve nefret söyleminin kolayca yeniden üretildiği bir platform haline gelmektedir.

Bir yeni medya platformu olarak Twitter anonim ve kullanıcı türevli içeriğe dayanan yapısı ile her gün milyonlarca iletinin dolaşıma girdiği bir mikroblog olması nedeni ile denetlenmesi güç bir alan olup; işletmenin daha önce kadınlara yönelik nefret söyleminin engellenmesine yönelik olarak katılım sağladığı WAM projesi gibi uygulamalara destek vermesi homofobik nefret söyleminin üretiminin sınırlandırılması açısından yarar sağlayabilir. Ayrıca yeni medya okuryazarlığına yönelik çalışmalar homofobik nefret söyleminin üretimi ve dağılımı açısından Twitter kullanıcıları arasında bir farkındalık yaratabilir.Ancak; eşcinselliğin Türkiye'de resmi ideolojik söylem ve kamusal alan içerisinde doğal olmayan bir durum olarak nitelendirilmesine bağlı olarak; yeni medya ortamlarında homofobik nefret söylemininin üretimi ve dağılımı tam olarak engellenemeyecektir. $\mathrm{Bu}$ bağlamda; ancak resmi ideolojik söyleme bağlı olarak kamusal alan içerisinde farklı cinsel yönelimlerin sistemli ve sürekli olarak ötekileştirilmesi sorunu ortadan kalkarsa; Twitter gibi yeni medya platformları eşcinsellere yönelik homofobik nefret söyleminin yeniden dolaşıma sokulduğu ve eşcinsel bireylerin temsiliyet gücünün sınırlı olduğu bir alan haline gelmekten öteye gidebilecektir.

\section{Kaynakça}

Akar, E. (2011). Sosyal Medya Pazarlaması, Ankara: Efil Yayınevi.

Avrupa Konseyi. (2014). Cinsel Yönelim veya Cinsiyet Kimliği Temelli Ayrımcılıkla Mücadele Avrupa Konseyi Standartları (çev. KAOS GL Derneği), Strazburg:Avrupa Konseyi Yayıncllık

Alacaoğlu, İ. (2013), Eşcinsel Edebiyatta Erkeklik Kurguları, İzmir: Ege Üniversitesi Sosyal Bilimler Enstitüsü Yayınlanmamış Yüksek Lisans Tezi.

Althusser, L. (2003). İdeoloji ve Devletin İdeolojik Aygıtları. (A. Tümertekin, Çev). İstanbul: İthaki Yayınları.

American Psychological Association. Homosexuality. Erişim:10.04.2015, http:// www.apa.org.

Başar, K. vd. (2010). Eşcinsellikle İlgili Yaygın Yanlışlar, Bilimsel Doğrular. Homofobi Kimin Meselesi. (s. 68-77). Ankara: Kaos GL. 
Barrett, M. (1997). Marx'tan Foucalt'a İdeoloji. İstanbul: Sarmal Yayınları.

Berelson, B. (1952). Content Analysis in Communication Research. New York: Free Press.

Bianet. (2015). Erişim:16.07.2015, https://m.bianet.org/biamag/lgbti/167837

Bottomore, T. (2005). Marksist Düşünce Sözlügü. M. Tunçay (Der.). İstanbul: İletişim Yayınları.

Boyd, D. vd. (2010). Tweet, Tweet, Retweet: Conversational Aspects of Retweeting on Twitter. 43'nd Hawaii International Conference on System Sciences. (s. 1-10). Hawaii. IEEE Conference Publications.

Bryant, K. ve Vidal, S. (2008). Introduction to Retheorizing Homophobias. Sexualities, 4, $387-396$.

Cammaerts, B. (2009). Radical Pluralism and Free Speech in Online Public Spaces. The Case of North Belgian Extreme Right Discourses. International Journal of Cultural Studies, 12(6), 555-575.

Candansayar, S. (2009). Bir Ötekileştirme Pratiği Olarak Cinselliğin Tıbbileştirilmesi ve Eşcinsellik. Anti Homofobi Kitabı. (s. 69-72). Ankara: Kaos GL.

Candansayar, S. (2011). Tibbın (Eş)cinselliğe Bakışı İçin Bir Arkeoloji Denemesi. Cogito Üç Aylık Düşünce Dergisi, Cinsel Yönelimler ve Queer Kuram Sayısl, 65$66,149-165$.

Comninos, A. (2013). The Role of Social Media and User-generated Content in Postconflict Peacebuilding. Washington DC: World Bank.

Cengiz K. vd. (2004). Hegemonik Erkekliğin Peşinden, Toplum ve Bilim, 101, 50-71.

Connell R. W. (2002). Masculinities and Men's Health, B Baron (Ed.). Gender in Interaction. Perspectives on Femininity and Masculinity in Ethnography and Discourse. . (s. 139-152). Philadelphia: John Benjamins Publishing Company.

Çabuk, D. ve Candansayar, S. (2010). Tıp ve Homofobi. Homofobi Kimin Meselesi. (s. 85-89). Ankara: Kaos GL.

Ertan, C. (2010). Homofobi: İnternet Gazetelerinde Okuyucu Yorumlarındaki Eşcinsellere Yönelik Tutumlar ve Söylemler. Ethos: Felsefe ve Toplumsal Bilimlerde Diyaloglar, 2 (3), 1-17.

Gramsci, A. (1978). Selections from Political Writings 1921-1926. Q. Hoare (Ed.). London: Lawrence and Wishart.

Fone, B. (2000). Homophobia: A History. New York: Picador.

Foucault, M. (1998). Cinselliğin Tarihi. H. Tufan, (Çev.). İstanbul: Afa Yayıncılık.

Foucault, M. (2003). İktidar ve Beden. İktidarın Gözü. I. Ergüden (Çev.). İstanbul: Ayrintı Yayınları.

Foulquie, P. (1998). Varoluşçunun Varoluşu. (Y. Şahan, Çev.). İstanbul: Toplumsal Dönüşüm Yayınları.

Gagliardone, I. vd. (2015). Countering Online Hate Speech. Paris: UNESCO 
Gelgeç, A. ve Öktem, P. (2008). Media Discourses On Homosexuality And Managing Heterosexism In Turkey. Art, Culture and Public Sephere: Expressive and Instrumental Values in Economic and Sociological Perspectives Conference. Venedik.

George, C. and Skerri, J. (2007). Web 2.0 and User-generated Content: Legal Challenges in the New Frontier. Journal of Information, Law and Technology (2). 1-22.

Gezgin, İ. (2010). Antik Yunan ve Roma Sanatında Cinsellik ve Erotizm. İstanbul: Alfa Yayınları.

Göregenli, M. (2009). Ayrımcılığın Şiddeti: Nefret Suçları. Anti Homofobi Kitabı. (s. 49-54). Ankara: Kaos GL.

Göregenli, M. (2010). "Zalimin Zırt dediği Yer.” Amargi (17).

Göregenli, M. (2011a). LGBT Bireylerin gündelik Yaşamda Karşılaştıkları Ayrımcılık. Ankara: Kaos GL.

Göregenli, M. (2011b). Heteroseksim, Homofobi ve Nefret Suçları: Sosyal Psikolojik Yaklaşım. Cogito Üç Aylık Düşünce Dergisi, Cinsel Yönelimler ve Queer Kuram Sayısl, 65- 66, 353-365.

Güngör, S. (2001). Althusser'de İdeoloji Kavramı. SDÜ İIBF Dergisi, 6 (2), 221-231.

Jenkins, H. (2002). Interactive Audiences The 'Collective Intelligence' of Media Fans, Erişim:10.10.2015, http://web.mit.edu/21fms/People/henry3/ collective\%20intelligence.html

İnceoğlu, Y. G. ve Çomak, N. E. (2009). Metin Çözümlemesi. İstanbul: Ayrıntı Yayınları. İnceoğlu, Y. (2012). Nefret Söylemi ve Nefret Suçları. İstanbul: Ayrıntı Yayınları.

İnceoğlu, Y. ve Çoban, S. (2014). Öteki»leştirme Sürecinde Medyanın Yeri. Y. İnceoğlu, ve S. Çoban. (Ed.). Azınlıklar, Ötekiler ve Medya. (s. 50-98). İstanbul: Ayrıntı Yayınları.

Kassing L. R. vd. (2005). Gender Role Conflict. Homophobia, Age, and Education as Predictors of Male Rape Myth Acceptance.Journal of Mental Health Counseling, 27 (4), 311-328.

KAOS GL. Sıkça Sorulan Sorular, Erişim:15.10.2015, http://www.kaosgl.org/sayfa. php?id

Kılıç, D. (2011). Bir Ötekileştirme Pratiği Olarak Basında Eşcinselliğin Sunumu: Hürriyet - Sabah Örneği (2008-2009). Gümüşhane Üniversitesi İletişim Fakültesi Dergisi, 1, 143-169.

Krippendorff, K. (2003). Content Analysis: An Introduction to its Methodology. London, Sage Publications.

Kur'an, Şuara Suresi, Ayet 165-166.

McCary, J. L. (1967). Human Sexuality. New York: D. Von Nostrand Company.

Nahya, N. (2011). İmgeler ve Ötekileştirme: Cadılar, Yerliler, Avrupalılar. Atılım Sosyal Bilimler Dergisi , 1 (1), 27-38.

Nişanyan, S. (2002). Sözlerin Soyağacı, Çağdaş Türkçenin Etimolojik Sözlüğü. İstanbul: Adam Yayınları. 
OECD. (2007). Participative Web: User-created Content, OECD Directorate for Science, Technology and Industry, Erişim:16.07.2015, http://www.oecd.org/ sti/38393115.pdf

OECD (2008), Measuring User-Created Content: Implications for the "ICT Access and Use by Households and Individuals" Surveys. Erişim:16.07.2015, http:// www.oecd.org/dataoecd/44/58/40003289.pdf.

O'reilly, T. ve Millstein, S. (2009). The Twitter Book. California: O’Reilly Media.

Oktan, A. (2008). Türk Sinemasında Hegemonik Erkeklikten Erkeklik Krizine: Yazı Tura ve Erkeklik Bunalımının Sınırları. Selçuk İletişim Dergisi, 5(2), 152-166.

Özdemir Akgündüz, G. (2013). Foucault'da İktidar Beden İlişkisi. Akademik Bakış Dergisi, 38, 1-16.

OpenUniversity, Being Digital:Writing a Good Tweet, Erişim 01.05.2018, https:// www.open.ac.uk/libraryservices/beingdigital/accessiblepdf-32-writing-agood-tweet.pdf

Padgug, R. (2001). “Cinsel sorunlar: Cinselliği tarih içinde yeniden düşünmek.” M.C. Vicinus vd. (Ed). Tarihten Gizlenenler Gey ve Lezbiyen Tarihine Yeni Bir Bakış. (s.53-63) Ankara: Phoenix.

Pleck, J. H. (1995). The Gender Role Strain Paradigm: An Update, R. F. Levant \& W. S. Pollack (Ed.). A New Psychology of Men, New York: Basic Books.

Rogers, E. (1986). Communication Technology: The New Media in Society. New York: Free Publishing.

Segal, L. (1992). Ağır Çekim: Değişen Erkeklikler Değişen Erkekler. İstanbul: Ayrıntı Yayınları.

Stanford Encyclopedia of Philosophy. (2011). Homosexuality. Erişim:15.10.2015, http://plato. stanford.edu/entries/homosexuality/

SocialBakers (2015), Erişim:21.10.2016, https://www.socialbakers.com/

Statista, Twitter Statistics, Erişim: 23.01.2016, https://www.statista.com/statistics/

Tevrat, Leviticus, 18:22.

Twitter, Using Twitter, Erişim: 23.09.2017, https://help.twitter.com/en/usingtwitter

We are Social (2018), Erişim: 23.04.2018, https://wearesocial.com/blog

World Health Organization. (2011). Stop Discrimination against Homosexual Men and Women, Erişim:10.10.2015, http://www.euro.who.int/en/what-we-do/ healthtopics.

Yetkin, N. (2009). Psikiyatrinin Homofobisi. Anti-Homofobi Kitabı. (s.79-83). Ankara: Kaos GL.

Yüksel, Ş. (2011) Eşcinsellik, Sosyal Dışlanma ve Ruh Sağlı̆̆ Sorunlarına Yaklaşım, Erişim:10.10.2015, http://kaosgl.org/sayfa.php?id=6261 